\title{
MENGATASI KONFLIK RUMAH TANGGA (STUDI BK KELUARGA)
}

\author{
Nurul Atieka \\ Universitas Muhammadiyah Metro
}

\section{PENDAHULUAN}

Semua orang dalam membina keluarga, menginginkan keluarga yang sakinah, yang mampu memberikan cinta dan kasih sayang pada anggota keluarganya, sehingga mereka memiliki rasa aman, tenteram, damai dan bahagia dalam mengusahakan tercapainya kesejahteraan hidup dunia dan akhirat.

Berbagai upaya dilakukan untuk meraih kebahagiaan dan kelanggengan suatu keluarga. Namun demikian perlu diingat bahwa pembentukan keluarga sakinah, yang diawali dengan perkawinan yang berarti "ikatan lahir batin antara seorang pria dengan seorang wanita sebagai suami istri dengan tujuan membentuk keluarga ( rumah tangga ) yang bahagia dan kekal berdasarkan ketuhanan Yang Maha Esa", atau dikatakan bahwa " perkawinan adalah persatuan cinta antara sepasang pria dan wanita yang dikukuhkan didepan petugas agama atau pencatatan sipil " tidak mudah untuk mewujudkannya. Ada yang bisa mewujudkan keluarga sakinah, ada yang kurang bahkan ada yang tidak bisa bahkan hancur ditengah jalan

Menurut Hadisubrata (2003), perkawinan adalah persatuan cinta. Cinta yang menjadi dasar perkawinan harus mempunyai unsur-unsur tertentu yang dapat menjamin kelanggengan suatu perkawinan.

1. Unsur pertama adalah "kehendak untuk membahagiakan pasangan"

Cinta suami-istri lebih merupakan suatu keputusan daripada hanya sekedar rasa kasmaran (cinta erros) saja. Perkawinan yang hanya didasarkan pada perasaan saja, kemungkinan akan menyesal, karena perasaan cinta asmara itu dapat datang dan pergi dengan cepat dan dapat berubah pada saat-saat menghadapi realitas kehidupan perkawinan

2. Unsur kedua "Kesetiaan"

Kesetiaan merupakan pelaksanaan konkrit dari kehendak untuk saling membahagiakan, yaitu akan tetap saling mencintai dan saling membahagiakan dalam keadaan seperti apapun ( baik suka maupun duka, dalam untung maupun malang). Kesetiaan ini menuntut usaha keras untuk tetap berpegang pada apa yang diputuskan, mau memperteguh dan memperbaharuinya, lebih-lebih saat menghadapi godaan, kekecewaan dan kesulitan 
3. Unsur ketiga "Pemberian diri secara total"

Yang berarti bahwa dirinya secara utuh ( Jiwa dan raganya) diserahkan kepada pasangannya, tidak terbagi-bagi. Pemberian secara total akan terwujud apabila kedua belah fihak mau terbuka dan saling mempercayai, mau berkorban dan mengesampingkan kepentingan pribadi, penuh perhatian dan tanggung jawab terhadap kebahagiaan pasangan, mau membantu dan melayani pasangannya.

\section{MENGAPA BIMBINGAN KELUARGA DIPERLUKAN ?}

Dalam usaha mewujudkan keluarga sakinah kadang seseorang perlu bantuan dan bimbingan. Ada beberapa hal yang melatar belakangi mengapa bimbingan perkawinan diperlukan (Walgito, 2001):

1. Masalah Kebutuhan Individu

Manusia merupakan mahluq hidup yang mempunyai kebutuhan-kebutuhan tertentu, dan kebutuhan merupakan pendorong timbulnya tingkah laku. Perkawinan juga merupakan usaha untuk memenuhi kebutuhan-kebutuhan yang dalam diri indiviu yang bersangkutan. Namun dalam perkawinan kadang -kadang atau justru individu tidak tahu apa yang harus dilakukan. Dalam keadaan seperti ini maka individu tersebut perlu bantuan orang lain atau perlu pembimbing dan konselor yang berperan membantu mengarahkan atau memberi pandangan tentang masalahnya.

2. Masalah perbedaan individu

Tidak ada manusia di dunia ini yang sama persis, masing-masaing individu berbeda satu sama lainnya. Dalam mencari pemecahan masalah, masing-masing individu mempunyai kemampuan yang berbeda-beda, ada yang cepat, ada yang lambat bahkan ada yang tidak bisa memecahkan masalahnya sendiri. Individu yang tidak bisa memecahkan permasalahannya, maka perlu bantuan orang lain atau perlu bimbingan dan konseling

3. Masalah Perkembangan Individu

Individu merupakan machluq yang berkembang. Dan dalam mengarungi perkembangan ini, kadang-kadang individu mengalami hal-hal yang tidak dapat dimengerti oleh individu yang bersangkutan, khususnya dalam hubungan antara pria dan wanita. Akibatnya dapat menimbulkan berbagai macam kesulitan yang menimpa diri individu tersebut. Untuk menghindarkan diri dari hal-hal yang tidak diinginkan, diperlukan bantuan orang lain untuk pengarahannya atau dengan kata lain perlu bimbingan dan konseling

\section{PENYEBAB KONFLIK PERKAWINAN DAN PEMECAHANNYA}

Konflik-konflik dalam perkawinan yang menyebabkan keretakan hubungan suami-istri atau bahkan menyebabkan perceraian,biasanya bersumberkan pada kepribadian suami istri dan hal-hal yang erat kaitannya dengan perkawinan (Hadisubrata, 2003) ; 
\begin{tabular}{l|l} 
Nurul Atieka & 47
\end{tabular}

1. Konflik yang bersumber pada kepribadian pada umumnya disebabkan oleh

a. Ketidak matangan kepribadian

Cinta suami istri seperti yang diuraikan pada pendahuluan di atas hanya dapat menjamin kebahagiaan dan kelanggengan satu perkawinan, kalau benar-benar diamalkan dalam kehidupan sehari-hari. Justru di sinilah letak kesulitannya, sebab masih ada faktor lain yang dapat menghambat terwujudnya cinta suami istri.

Kalau salah satu atau kedua belah fihak memiliki kepribadian yang belum matang atau belum dewasa dalam arti belum mempunyai tanggung jawab, masih suka ikut-ikutan ( tidak punya prinsip ) masih suka memburu kesenangannya sendiri kemungkinan akan menyebabkan permasalahan dalam perkawinan.

Maka diharapkan calon suami istri yang akan mengikat perkawinan, sudah memiliki kepribadian yang matang dalam arti kepribadian yang mampu melaksanakan tugas dan panggilan hidup atas tanggung jawab sendiri. la sudah tidak menjadi tanggung jawab orang tua, sudah dapat memimpin diri sendiri, mengurusi persoalan -persoalan hidupnya sendiri, dan bertanggung jawab atas nasib orang-orang yang menjadi tanggungannya, punya gambaran diri atau citra diri positif

b. Adanya sifat-sifat kepribadian yang tidak cocok untuk menjalin hubungan perkawinan Watak-watak kepribadian yang tidak cocok untuk menjalin hubungan perkawinan dan apabila ini dimiliki sepasang suami istri maka akan terjadi konflik dalam kehidupan perkawinannya, misalnya egois, tertutup, keras kepala, mudah tersinggung, defensif, berusaha membenarkan atau menutupi kesalahannya, selalu curiga, kurang percaya diri. Apabila sifat ini dibawa dalam kehidupan perkawinan maka akan menimbulkan konflik, kejengkelan, kebencian dan tidak jarang membuat perkawinan berantakan

c. Adanya kelainan mental

Kelainan mental yang mudah memicu konflik perkawinan adalah perilaku abnormal, homosek, lesbian, psikosis dsb

2. Konflik yang bersumber pada hal-hal yang erat kaitannya dengan perkawinan, antara lain menyangkut masalah-masalah sebagai berikut :

a. Keuangan

Keuangan dapat menimbulkan konflik kalau ada perbedaan pendapat antara suami-istri tentang makna uang bagi mereka, kalau penghasilan tidak stabil, salah satu atau keduanya tidak terbuka mengenai pemasukan dan pengeluaran, kalau salah satu atau keduanya tidak bijaksana dalam membelanjakan uang.

Agar keuangan tidak menjadi penyebab konflik dalam keluarga maka harus diuasahakan adanya ekonomi keluarga yang stabil.yaitu dilaksanakannya : 
- Keluarga sebagai unit usaha

keluarga sebagai unit usaha bertugas untuk menjaga agar pemasukan lebih besar dari pengeluaran. Kalau hal ini disebabkan karena faktor kurangnya pendapatan keluarga maka perlu diusahakan penghasilan tambahan agar paling tidak kebutuhan pokok terpenuhi. Namun kalau disebabkan karena kurangnya perhitungan dalam membelanjakan uang, maka perlu diadakan pengaturan keuangan keluarga yang lebih baik.

- Perencanaan anggaran keluarga

Anggaran keluarga perlu dibuat untuk menstabilkan keuangan. Perencanaan ini mencoba memperhitungkan dengan matang penghasilan yang diterima dan membagi-baginya untuk memenuhi kebutuhan keluarga, sehingga ada jaminan semua kebutuhan terpenuhi. Suami-istri harus membuat prioritas kebutuhan, sehingga diketahui kebutuhan primer, skunder dan tertier. Semua pendapatan dan pengeluaran perlu dicatat untuk memudahkan pengontrolan dan bisa dijadikan bahan penyusunan anggaran berikutnya. Disiplin dalam menjalankan anggaran akan meningkatkan kesejahteraan keluarga dan menghindarkan pemakaian anggaran yang tidak perlu

- Keterbukaan dalam hal keuangan

Perencanaan anggaran keluarga dan pelaksanaanya, hanya mungkin terwujud kalau ada keterbukaan diantara suami istri. Keterbukaan dalam hal keuangan dapat menghindarkan salah faham dan kecurigaan antar anggota keluarga, sehingga kehidupan keluarga menjadi lebih tenang.

b. Kehidupan sosial

Kehidupan sosial dapat menimbulkan konflik kalau suami istri mempunyai temperamen sosial yang berbeda, kalau salah satu kurang mengerti kebutuhan sosial pasangannya, kalau salah satu atau kedua belah fihak menggunakan kegiatan sosial untuk menutupi ketidak puasannya terhadap situasi keluarga.

Untuk menghindarkan semua itu maka perlu kesadaran suami-istri akan pengetahuan tentang hak dan kewajiaban masing-masing, dan kesediaan untuk melaksanakannya, dan ada kehendak untuk membahagiakan pasangan, kesetiaan dan penyerahan diri secara total

c. Pendidikan anak

Pendidikan anak dapat menimbulkan konflik kalau suami istri memiliki perbedaan prinsip dalam mendidik anak, dan kalau salah satu atau keduanya bersikap pilih kasih Suami-istri hendaknya bersepakat, satu kata, bersikap sama dalam mendidik anak dan setia dalam melaksanakan kesepakatan tersebut 
d. Masalah agama

Kalau suami istri berbeda agama maka bisa menimbulkan akibat :

- tidak adanya kebersamaan dan sharing dalam hal-hal yang prinsip, menimbulkan kesepian, kekosongan, dan frustasi yang mendalam. Apalagi kedunya sama kuat berpegang pada agmanya, konflik hebat tak terhindarkan

- setelah punya anak, dapat terjadi perbedaan pendapat tentang agama yang harus dianut anaknya. Dan dapat membingungkan anak

- dapat juga terjadi ketegangan dengan mertua dan saudara-saudara ipar, sehingga merasa terasing dari keluarga pasangan.

Dalam memilih pasangan hidup hendaknya yang seiman, sehingga semua permasalahan keluarga dapat diselesaikan dengan mempedomani tuntunan agama (bagi yang beragama islam bisa segera kembali kepada Al-Qur'an dan hadist)

e. Hubungan dengan mertua-ipar

Hubungan dengan mertua-ipar dapat menimbulkan konflik kalau tidak ada kesatuan terhadap orang tua-ipar kedua belah fihak, kalau salah satu atau keduanya sangat tergantung pada orang tuanya atau merasa mempunyai tanggung jawab penuh terhadap kakak-adiknya.

Untuk memasuki kehidupan keluarga suami istri harus sudah bisa mandiri dan berusaha mempersatukan dua keluarga dari suami-istri tersebut. Masing-masing menyadari akan batas-batas tanggung jawab terhadap keluarga asal.

f. Penyelewengan dalam hubungan seksual

Penyelewengan dalam hubungan seksual dapat menimbulkan konflik berat bagi suami istri, bahkan kadang berakhir dengan perceraian atau pisah kebo, kalau fihak yang menjadi korban tidak bisa memaafkan dan mempercayai pasangannya.

Penyelewengan hendaknya dihindari, dan kalau sudah terlanjur hendaknya segera diakhiri, serta bangun kepercayaan pasangan. Bangun komunikasi yang baik yang akan bisa memecahkan segala permaslahan

g. Ketidak Puasan seksual

Ketidak puasan seksual dan buruknya hubungan suami istri merupakan lingkaran setan yang tak berujung dan berpangkal. Ketidak puasan dalam hubungan seksual akan berakibat pada hubungan suami-istri dan buruknya hubungan suami istri akan membawa akibat pula dalam hubungan seksual.

Penyebab ketidak puasan hubungan suami istri antara lain :

- anggapan yang salah mengenai aktifitas seksual. Misal : dalam hubungan seksual yang harus aktif adalah pria, sehingga kalau perempuan menginginkan harus menunggu ajakan pria. Demikian pula bahwa membiacarakan seks adalah tabu. 
Kalau ada permasalahan seksual antara suami istri tabu untuk dibicarakan. Sehingga tidak ada pemecahannya.

Antara suami istri hendaknya terbuka tentang semua permasalahan termasuk permasalahan seks dan berusaha memenuhi kebutuhan keduanya

- Hambatan psikologis dan fisik

Rasa takut yang berlebihan akan kehamilan bisa menyebabkan istri tidak mampu memberikan respon seksual seperti yang diharapkan suami, sehingga istri tidak dapat menikmati dan mengecewakan suami. Ketakutan akan kegagalan dalam hubungan seks yang biasanya diderita oleh suami, dapat mengakibatkan kegagalan yang sesungguhnya. Sehingga kedua belah fihak merasa tidak puas.

Demikian pula hambatan fisik yang berbentuk kelainan-kelainan seksual, seperti impotensi, homoseks, sadisme atau masosisme dan lain sebaginya dapat merusak keserasian hubungan seksual suami -istri Untuk itu diperlukan usaha yang sungguh-sungguh agar semua beban psikilogis dan penyakit fisik terbebaskan

\section{PENUTUP}

Keluarga sakinah yang didambakan setiap pasangan suami-istri sangat enak untuk didengarkan, tetapi sulit diwujudkan. Maka perlu diusahakan dengan sungguh-sungguh tanpa mengenal putus asa. Membina keluarga sakinah adalah usaha suami istri. Kalau ada hambatan maka harus diatasi bersama. Kalau usaha hanya dijalankan hanya dari sebelah fihak, maka tujuan tidak akan tercapai dan segala masalah tidak akan terpecahkan. Hambatan-hambatan akan selalu ditemui, namun dengan usaha yang benar tanpa mengenal lelah dari kedua belah fihak akan membuahkan hasil. Kalau hambatan yang ditemui tidak bisa dipecahkan berdua maka diperlukan bantuan orang lain. Suami istri tidak perlu malumalu untuk mengungkapkan permaslahannya kepada orang yang dianggap mampu untuk membnatu menyelesaikan masalah keluarga.

\section{DAFTAR PUSTAKA}

Walgito, B. (2001). Bimbingan dan Konseling Perkawinan, Yayasan Penerbit Fakultas Psikologi Universitas Gajah Mada, Yogyakarta

Hadisubrata. (2003). Keluarga dalam Dunia Modern, Tantangan dan Pembinaannya, BPK Gunung Mulia, Jakarta

Pimpinan Pusat Aisyiyah. (Tanpa tahun). Membina Keluarga Sakinah, Yogyakarta: Bengkel Keluarga, 